\title{
A Conceptual Framework for the Development of a MOOCs-Based Knowledge Repository to Enhance Digital Entrepreneurs' Competencies
}

\author{
Nattaphol Thanachawengsakul
}

\begin{abstract}
A conceptual framework for the development of a MOOCs-based knowledge repository using a digital knowledge engineering learning process to enhance digital entrepreneurs' competencies as follows: (1) the digital knowledge engineering learning process was divided into six steps: (1.1) knowledge creation, (1.2) knowledge storage, (1.3) knowledge acquisition, (1.4) knowledge access, (1.5) knowledge sharing and (1.6) knowledge application; (2) the knowledge repository consisted of three subsystems: (2.1) user management system, (2.2), knowledge management system and $(2.3)$ report management system; (3) the MOOCs-based learning management system comprised six elements: (3.1) reading material, (3.2) video lectures, (3.3) discussion forums, (3.4) quizzes, (3.5) assignment and (3.6) certificate; and (4) digital entrepreneurs' competencies comprised three levels: (4.1) use of digital technology for collaboration, (4.2) use of digital technology for work and (4.3) digital accessibility and awareness.
\end{abstract}

Index Terms-Knowledge repository, MOOCs, digital knowledge engineering, digital entrepreneur competencies.

\section{INTRODUCTION}

Thailand is entering the digital era with its official launch of national strategy 4.0 to accelerate the Kingdom's development, which is designed to support and promote innovation, technology and creative thinking [1]. The strategy formally came into effect with its publication in the $12^{\text {th }}$ National Economic and Social Development Plan B.E. 2560-2564 (2017-2021) [2] as fundamental strategic factors in economic development covering all areas of economics, e.g. investment for research and development, development of science, technology and innovation, as well as workforce development for future and current labor markets consistent with the production of goods and services, and the evolution of technology. This also includes human development to equip professionals where people can adjust themselves to a changing environment; this is especially associated with human capital development through improving the quality of education, learning, skills and public health services in all regions of the Kingdom according to the 1st national strategy: human capital strengthening and development in regions of

Manuscript received July 25, 2019; revised March 12, 2020. This work was supported in part by the Chandrakasem Rajabhat University under Award No. 2/2562, Fiscal Year 2019.

Nattaphol Thanachawengsakul is with the Chandrakasem Rajabhat University, Bangkok, Thailand (e-mail: Nattaphol.t@chandra.ac.th). the Kingdom, according to the 1st national strategy: human capital strengthening and development in regard to information system development, workforce demand and production with integrated planning of related agencies, establishment of information centers, providing consulting services for new entrepreneurs and freelancers in response to the 20-year national strategy (2016): [3] developing the potential of human resources and promoting equal opportunities in society.

As the dynamics of the $21^{\text {st }}$ century affect all organizations today, they have to face significant change and apply cutting-edge technology to knowledge management. The process involves data associated with concepts, abilities and skills of personnel being collected and stored in the system. Knowledge management (KM) can be used for many purposes such as communication, sharing concepts, knowledge and skills across organizations leading to best practice, adaptability, problem-solving abilities and knowledge acquisition through development [4]. A KM system makes it easier to find information so people can actually apply knowledge in action in workplaces. Tools and cutting-edge technology, including digital technology, information systems for management and knowledge repositories are leveraged to provide people with easy access to information anywhere and anytime through an internet connection [5].

In 2012, MOOCs or Massive Open Online Courses were widely used by the top universities in the world. According to studies, MOOCs focus on cutting-edge technology education associated with the use of the internet and computers to assist with learning and teaching. MOOCs are considered educational resources enabling students and people to access education with open courseware (OCW) [6]. As previously mentioned, the role of entrepreneurs in economic development planning in Thailand today does not concern only investment or income but also structural change in business and society; immense value results from entrepreneurs' contribution to the economy [7]. In addition, human capital increasingly becomes important and many organizations have had to review their current practices, analyze the roles of performance management and enhance employees' competencies. Therefore, enhancement of employees' competencies should align with core competencies and the objectives of organizations so as to lead to the desired outcomes and enable employees to reach the goals they set for themselves [8]. In this paper, the findings suggest that entrepreneurs were facing a problem in meeting the demand for a workforce with specific skills, including job-related, professional, academic, ethics and moral skills. The lack of qualified employees is a serious problem for 
organizations since those skills are considered as employability skills, so there should be continuing professional development allowing employees to improve their capabilities [9].

Due to the importance of developing the potential of people in the country and accelerating economic growth with the application of innovation, technology and creative thinking for the knowledge-based economy, as well as awareness of the problems and development of entrepreneurs as drivers of economic growth in the country, the researcher came up with an idea in regard to a conceptual framework for development of knowledge repository MOOCs using a digital knowledge engineering learning process to enhance digital entrepreneurs' competencies in order to help them improve their knowledge, skills, abilities and attitudes for effective performance.

\section{OBJECTIVES OF THE RESEARCH}

1) Synthesis of a conceptual framework of a MOOCs-based knowledge repository using a digital knowledge engineering learning process to enhance digital entrepreneurs' competencies.

2) Development of a conceptual framework of a MOOCs-based knowledge repository using a digital knowledge engineering learning process to enhance digital entrepreneurs' competencies.

\section{ReSEARCH Methodology}

Stage I: Regarding the synthesis of a conceptual framework of a MOOCs-based knowledge repository using a digital knowledge engineering learning process to enhance digital entrepreneurs' competencies, the researcher conducted studies, analysis and synthesis from documents, textbooks, academic journals and relevant research papers from both domestic and international sources, published during 2001-2019 using a content analysis approach.

Stage II: The conceptual framework of a MOOCs-based knowledge repository using a digital knowledge engineering learning process to enhance digital entrepreneurs' competencies was developed by conducting studies, analysis and synthesis through Stage I of the research.

\section{RESEARCH FINDINGS}

Stage I: The synthesis process for the conceptual framework of a MOOCs-based knowledge repository using a digital knowledge engineering learning process to enhance digital entrepreneurs' competencies was as follows:

\section{A. Digital Knowledge Engineering Learning Process}

The result of the synthesis of the digital knowledge engineering learning process is illustrated in Table I:

According to the synthesis result indicated in Table I, it can be summarized that the digital knowledge engineering learning process comprises six steps: 1) knowledge creation, 2) knowledge storage, 3) knowledge acquisition, 4) knowledge access, 5) knowledge sharing and 6) knowledge application.
TABLE I: RESULT OF SYNTHESIS OF DIGITAL KNOWLEDGE ENGINEERING LEARNING PROCESS

\begin{tabular}{|c|c|c|c|c|c|c|}
\hline $\begin{array}{r}\text { Digital } \\
\text { Knowledge } \\
\text { Engineering } \\
\text { Learning } \\
\text { Process }\end{array}$ & 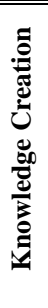 & 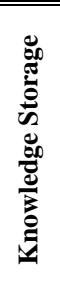 & 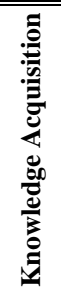 & 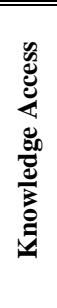 & 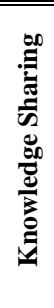 & 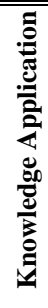 \\
\hline Mizoguchi, R. [10] & $\checkmark$ & $\checkmark$ & $\checkmark$ & $\checkmark$ & $\checkmark$ & $\checkmark$ \\
\hline $\begin{array}{l}\text { Thanachawengsakul, N., } \\
\text { Wannapiroon, P., and } \\
\text { Nilsook. P. [5] }\end{array}$ & $\checkmark$ & $\checkmark$ & $\checkmark$ & $\checkmark$ & $\checkmark$ & $\checkmark$ \\
\hline $\begin{array}{l}\text { Preece, A., Flett, A., } \\
\text { Sleeman, D. et al. [11] }\end{array}$ & $\checkmark$ & $\checkmark$ & $\checkmark$ & $\checkmark$ & $\checkmark$ & $\checkmark$ \\
\hline $\begin{array}{l}\text { Center of Excellence for } \\
\text { Unified Knowledge and } \\
\text { Language Engineering [12] }\end{array}$ & & $\checkmark$ & $\checkmark$ & $\checkmark$ & & \\
\hline ICT MOPH [13] & $\checkmark$ & $\checkmark$ & $\checkmark$ & $\checkmark$ & $\checkmark$ & \\
\hline $\begin{array}{c}\text { Digital Knowledge } \\
\text { Engineering Learning } \\
\text { Process }\end{array}$ & $\checkmark$ & $\checkmark$ & $\checkmark$ & $\checkmark$ & $\checkmark$ & $\checkmark$ \\
\hline
\end{tabular}

\section{B. Knowledge Repository System}

The result of the synthesis of the knowledge repository system is illustrated in Table II:

TABLE II: RESULT OF SYNTHESIS OF KNOWLEDGE REPOSITORY SYSTEM

\begin{tabular}{|c|c|c|c|c|}
\hline $\begin{array}{r}\text { Knowledge } \\
\text { Repository } \\
\text { System }\end{array}$ & 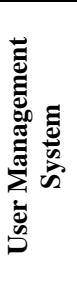 & 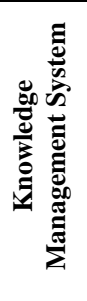 & 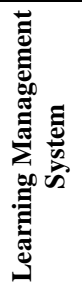 & 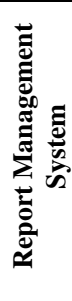 \\
\hline Training Industry [14] & $\checkmark$ & $\checkmark$ & $\checkmark$ & $\checkmark$ \\
\hline $\begin{array}{l}\text { Fabio, F. B. and Veruska, D. } \\
\text { S. C. [15] }\end{array}$ & $\checkmark$ & $\checkmark$ & & $\checkmark$ \\
\hline Theeraroungchaisri, A. [16] & $\checkmark$ & $\checkmark$ & $\checkmark$ & $\checkmark$ \\
\hline $\begin{array}{l}\text { Rodpai, A. and } \\
\text { Kittiphattanabawon, N. [17] }\end{array}$ & $\checkmark$ & $\checkmark$ & & $\checkmark$ \\
\hline Kokaew, P. [18] & $\checkmark$ & $\checkmark$ & & $\checkmark$ \\
\hline Phetwong, W [19] & $\checkmark$ & $\checkmark$ & & $\checkmark$ \\
\hline $\begin{array}{c}\text { Knowledge Repository } \\
\text { System }\end{array}$ & $\checkmark$ & $\checkmark$ & & $\checkmark$ \\
\hline
\end{tabular}

According to the result of the synthesis indicated in Table II, the knowledge repository system is divided into three subsystems consisting of: 1) user management system, 2) knowledge management system and 3) report management system.

\section{Massive Open Online Course System (MOOCs)}

The result of the synthesis of the elements of a MOOCs-based learning management system is illustrated in Table III:

As shown in Table III, a MOOCs-based learning management system comprises six elements: 1) reading material, 2) video lectures, 3) discussion forums, 4) quizzes, 5) assignment and 6) certificate. 
TABLE III: RESULT OF SYNTHESIS OF ELEMENTS OF MOOCS-BASED LEARNING MANAGEMENT SYSTEM

\begin{tabular}{|c|c|c|c|c|c|c|}
\hline Elements of & 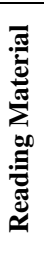 & 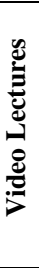 & 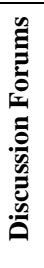 & 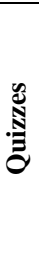 & 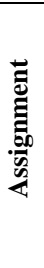 & 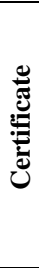 \\
\hline Wang, J. [20] & $\checkmark$ & $\checkmark$ & $\checkmark$ & $\checkmark$ & $\checkmark$ & \\
\hline DSTI [21] & $\checkmark$ & $\checkmark$ & $\checkmark$ & $\checkmark$ & $\checkmark$ & $\checkmark$ \\
\hline Kolowich, S. [22] & $\checkmark$ & $\checkmark$ & $\checkmark$ & $\checkmark$ & $\checkmark$ & $\checkmark$ \\
\hline Nilsook, P. [23] & $\checkmark$ & $\checkmark$ & $\checkmark$ & $\checkmark$ & $\checkmark$ & \\
\hline $\begin{array}{l}\text { Thailand Cyber University } \\
\text { [24] }\end{array}$ & $\checkmark$ & $\checkmark$ & $\checkmark$ & $\checkmark$ & $\checkmark$ & $\checkmark$ \\
\hline Theeraroungchaisri, A. [16] & $\checkmark$ & $\checkmark$ & $\checkmark$ & $\checkmark$ & $\checkmark$ & \\
\hline $\begin{array}{l}\text { Tinnawas, N. and } \\
\text { Thammetar, T. [6] }\end{array}$ & $\checkmark$ & $\checkmark$ & $\checkmark$ & $\checkmark$ & $\checkmark$ & $\checkmark$ \\
\hline $\begin{array}{l}\text { Wipawin, N. and } \\
\text { Withayawuttikul, R. [25] }\end{array}$ & $\checkmark$ & $\checkmark$ & $\checkmark$ & $\checkmark$ & $\checkmark$ & $\checkmark$ \\
\hline $\begin{array}{c}\text { Elements of } \\
\text { MOOCs-Based Learning } \\
\text { Management System }\end{array}$ & $\checkmark$ & $\checkmark$ & $\checkmark$ & $\checkmark$ & $\checkmark$ & $\checkmark$ \\
\hline
\end{tabular}

\section{Digital Entrepreneurs' Competencies}

The researcher carried out a synthesis of digital entrepreneurs' competencies based on digital literacy by using instruments for assessing digital competency aligning with international standards and globally recognized for digital literacy certification, as illustrated in Table IV:

As shown in Table IV, digital entrepreneurs' competencies comprised three levels:

Level 1: use of digital technology for collaboration, consisting of three elements, i.e. online collaboration, digital media program and digital literacy.

Level 2: use of digital technology for work, consisting of three elements, including the use of MS Excel and MS PowerPoint.

Level 3: digital accessibility and awareness, consisted of three elements, i.e. computer usage, internet usage and digital literacy.

Stage II: Development of a conceptual framework of a MOOCs-based knowledge repository using a digital knowledge engineering learning process to enhance digital entrepreneurs' competencies.

Based on studies, analysis and synthesis from documents, textbooks, academic journals and relevant research papers from both domestic and international sources conducted in Stage I, a summary of a conceptual framework of a MOOCs-based knowledge repository using a digital knowledge engineering learning process to enhance digital entrepreneurs' competencies is shown in Fig. 1 below:

Fig. 1 defines the elements of a conceptual framework of a MOOCs-based knowledge repository using a digital knowledge engineering learning process to enhance digital entrepreneurs' competencies:

1) Stakeholders were divided into two groups: 1.1) Instructors at higher education institutions and the Office of the Higher Education Commission and 1.2) entrepreneurs in small and medium enterprises with experience in information and communication technology.

2) Digital knowledge engineering learning process - learning management by experts, skillful and experienced people that offered entrepreneurs the opportunity to perform their own studies, discover information and share knowledge to find out answers about topics that interested them. The process included six steps: 2.1) knowledge creation, 2.2) knowledge storage, 2.3) knowledge acquisition, 2.4) knowledge access, 2.5) knowledge sharing and 2.6) knowledge application.

3) The MOOCs-based knowledge repository was developed by a software package that facilitated access to information anywhere and anytime over an internet connection, with a responsive design so it can be used on any device. The elements of the system were as follows:

a) Knowledge repository system: the software developed for learning management to enhance digital entrepreneurs' competencies consisted of three subsystems: 1) user management system, 2) knowledge management system and 3) report management system.

TABLE IV: RESULT OF SYNTHESIS OF DIGITAL ENTREPRENEURS' COMPETENCIES

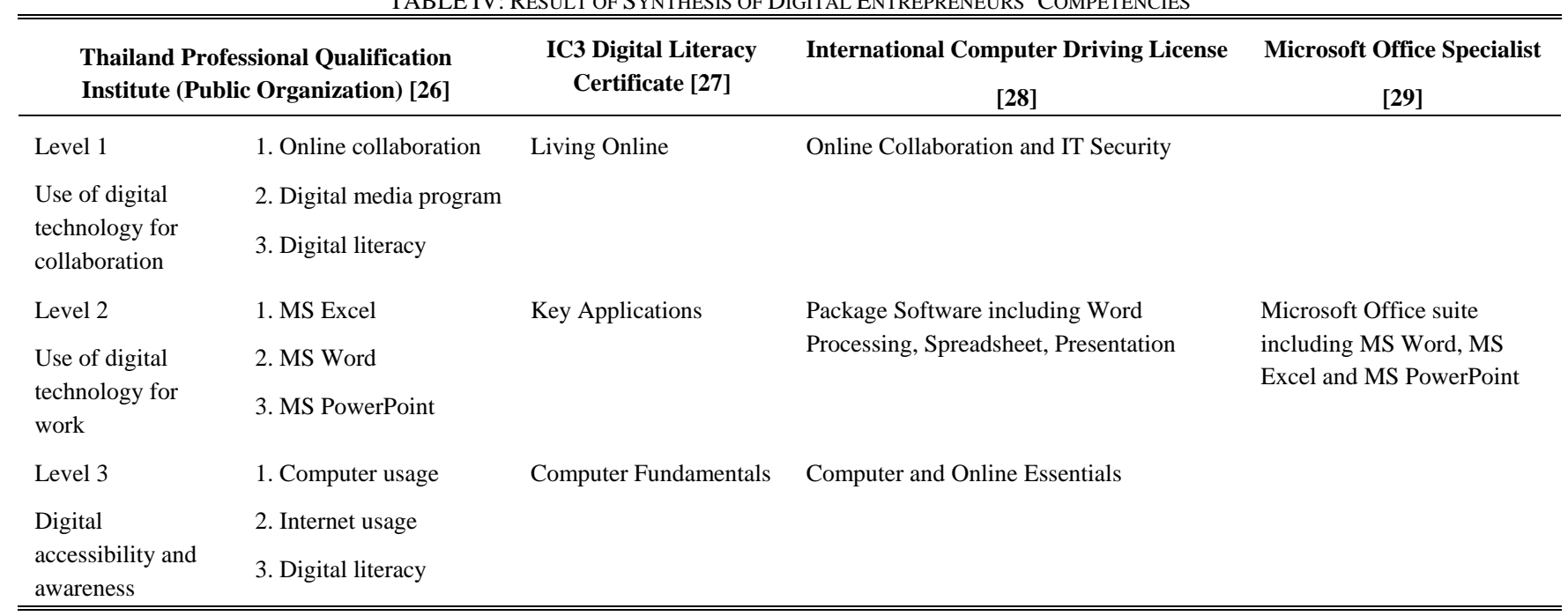




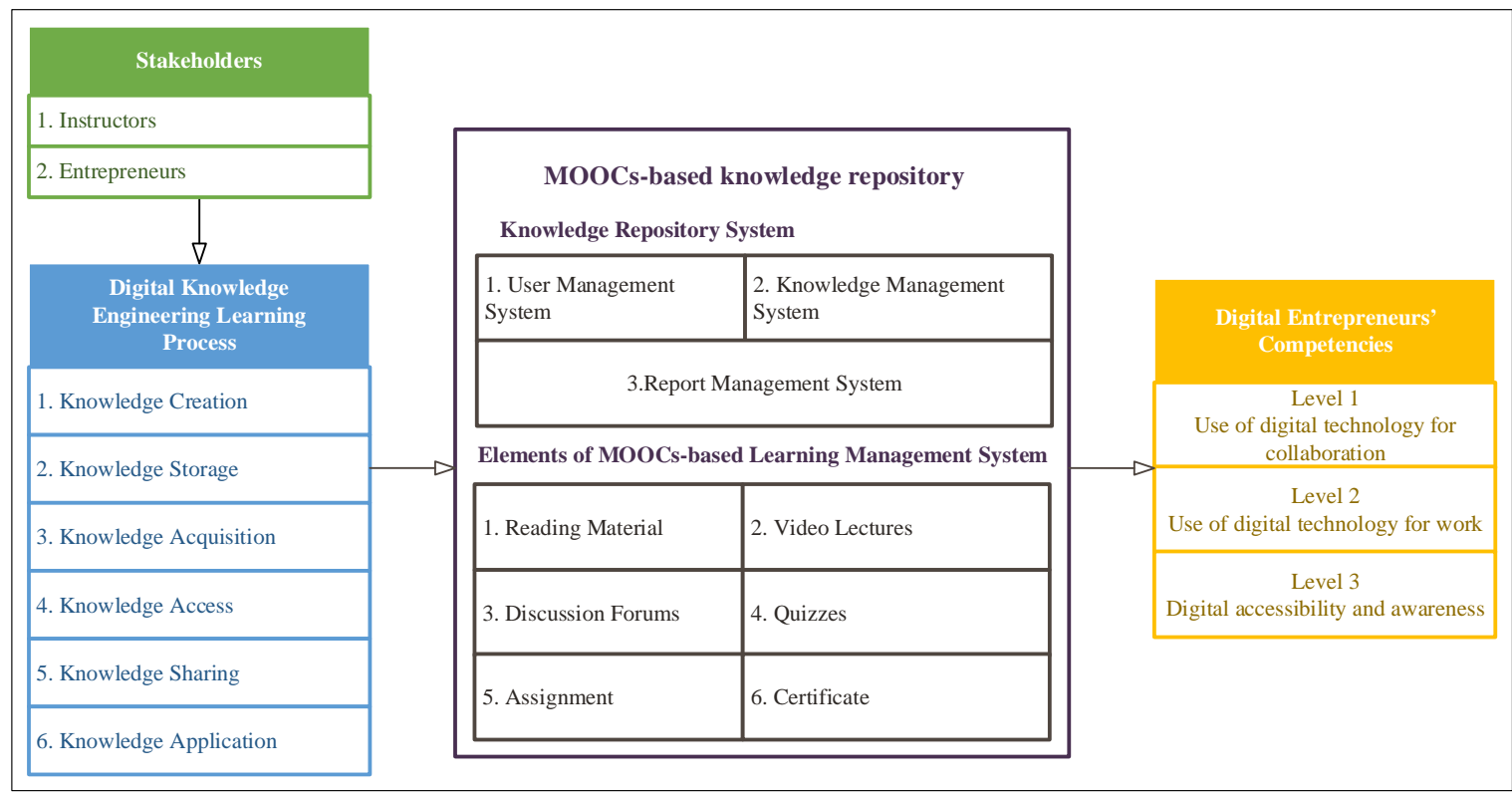

Fig. 1. Conceptual framework of a MOOCs-based knowledge repository using a digital knowledge engineering learning process to enhance digital entrepreneurs' competencies.

b) MOOCs-based knowledge repository: the software was designed to act as an open educational resource made available on the internet to provide entrepreneurs with the information in the knowledge repository. It was developed for use as self-study material for independent study, which is freely accessible without limitations of place or time. The MOOCs-based learning management system comprises six elements: 1) reading material, 2) video lectures, 3) discussion forums, 4) quizzes, 5) assignment and 6) certificate.

4) Digital entrepreneurs' competencies were defined as aspects of knowledge, skills and attributes, which entrepreneurs could develop through the MOOCs-based learning management system. The competencies were divided into three levels:

Level 1: use of digital technology for collaboration, consisting of three parts, i.e. online collaboration, digital media program and digital literacy.

Level 2: use of digital technology for work, consisting of three elements, including the use of MS Excel and MS PowerPoint.

Level 3: digital accessibility and awareness, consisting of three elements, i.e. computer usage, internet usage and digital literacy.

\section{Conclusions}

In regard to the development of a conceptual framework of a MOOCs-based knowledge repository using a digital knowledge engineering learning process to enhance digital entrepreneurs' competencies based upon the information gathered from documents, textbooks, academic journals, concepts and theories of relevant research paper from both domestic and international sources, as well as analysis and synthesis of data using a content analysis approach, the elements of the concepts included stakeholders, digital knowledge engineering learning processes, MOOCs-based knowledge repositories and digital entrepreneurs' competencies. This study was consistent with the concept of teachers' professional development for MOOCs-based education (Massive Open Online Courses), written and compiled by the Thailand Cyber University Project, Office of Higher Education Commission [24], which states that information and communication technology is used in educational organizations worldwide so as to provide an alternative to how education is delivered; it enables students to progress through self-study at anytime and anywhere. MOOCs were involved in courses and curriculum design for online education provided by educational institutions offering students opportunities to choose courses based on their own interests without registration fees. This study was also consistent with the concept of education and learning development for people of all ages set out in the National Education Plan of Thailand B.E. 2560-2574 (2017-2031) [30], which has the objectives of an opportunity guarantee of education, equality in education, educational development, educational standards, and employment and income under the context of the Thai and global economies in a society driven by innovative technology and creative thinking as well as wisdom, lifelong learning and a supportive learning environment. This will allow students to perform their own studies, discover information and share knowledge, whereas teachers or experts can use their expertise to pass on knowledge through digital technology [5], [31]-[33].

\section{SugGestions}

The researcher would like to make suggestions and recommendations, which may be taken from this study for future research:

1) The development of future learning ecosystems according to the concept of a MOOCs-based knowledge repository using a digital knowledge engineering learning process to describe the roles of teachers and entrepreneurs in the learning environment as well as with a digital knowledge engineering learning process through the use of a MOOCs-based knowledge repository.

2) The development of a MOOCs-based knowledge 
repository using a digital knowledge engineering learning process.

3) The implementation of a learning ecosystem based on a digital knowledge engineering learning process in teaching, so as to enhance the competencies of digital entrepreneurs who use MOOCs-based knowledge repositories alongside digital knowledge engineering learning processes.

\section{CONFLICT OF INTEREST}

The authors declare no conflict of interest.

\section{AUTHOR CONTRIBUTIONS}

Nattaphol Thanachawengsakul, Ph.D. conducted research to synthesis and development the conceptual framework of the research, being advised and until the research finished.

Assoc. Prof. Panita Wannapiroon, Ph.D. advised and designed the conceptual framework of the research and checked, including to audit the research methodology. She checked content of the research.

All research were approved it.

\section{ACKNOWLEDGMENT}

I would like to express my sincere gratitude to Chandrakasem Rajabhat University for your generous offer of research funding under Award No. 2/2562, Fiscal Year 2019, and appreciate for the owners of research articles, documentary, textbooks, and all sources of information. Without their valuable opinions and ideas, the research would not have been accomplished.

\section{REFERENCES}

[1] CEBIT ASEAN Thailand. (October 2018). CEBIT elevates Thai entrepreneurs to the digital age of Thailand. [Online]. Available: https://bit.ly/2MdSukG

[2] Ministry of Information and Communication Technology, Digital Development Plan for Economy and Society; Bangkok: Ministry of Information and Communication Technology, 2016.

[3] The Prime Minister, 20-Year National Strategic Plan, Bangkok: The Prime Minister, 2018.

[4] T. Maneetum, Study of Problem Images and Knowledge Management Approaches, Information Technology and Communication Service Centers at Phayao University, Phayao: Phayao University, 2014.

[5] N. Thanachawengsakul, P. Wannapiroon, and P. Nilsook, "How a digital knowledge engineering learning process can enhance technical skills in software engineering," World Transactions on Engineering and Technology Education, 2018, vol. 16, no. 3, pp. 312-316.

[6] N. Tinnawas and T. Thammetar, "The study of massive open online course model for Thai higher education," Veridian e-Journal, Silpakorn University, 2016, vol. 9, no. 3, pp. 1463-1479.

[7] Y. Khelbmas, "The importance of being a entrepreneur today," FEU Academic Review, 2008, vol. 1, no. 2, pp. 45-51.

[8] T. Setthabut, "A study of competency needs of human resource staff for industry sector," Veridian e-Journal, 2012, vol. 5, no. 2, pp. 426-448.

[9] W. Lalitsasivimon and N. Chinfuk, "Desirable skills expectation of entrepreneurs in Southern Area," MSU Journals, vol. 36, no. 5, pp. 133-141.

[10] R. Mizoguchi, "Knowledge engineering," The Authors and IOS Press, 2019, pp. 69-80.

[11] A. Preece, A. Flett, D. Sleeman et al., "Better knowledge management through knowledge engineering," IEEE Intelligent Systems, 2001, vol. 1, no. 16 , pp. 36-43.

[12] Center of Excellence for Unified Knowledge and Language Engineering. (July 2019). Research in knowledge engineering and language engineering. [Online]. Available: https://bit.ly/310DBGX

[13] ICT MOPH, Knowledge Management Procedure, Bangkok: MOPH, 2018.
[14] Training Industry. (July 2019). Knowledge Repositories. [Online]. Available: https://bit.ly/2YlFxfi

[15] F. B. Fabio and S. C. Veruska, "Ipea's knowledge repository," in Proc. $16^{\text {th }}$ European Conference on Knowledge Management at Udine - Italy, 2015, pp. 1-11.

[16] A. Theeraroungchaisri. (October 2018). MOOC and the future of Thai education in the digital age. [Online]. Available: https://www.nectec.or.th/ace2016/pdf/session7_01_Anuchai.pdf

[17] A. Rodpai and N. Kittiphattanabawon, "Knowledge management system for gripen simulator maintenance, wing 7," presented at the $8^{\text {th }}$ Hatyai National and International Conference, Thailand, June 22, 2017, pp. 358-369.

[18] P. Kokaew, "Development of digital repository of the Faculty of Veterinary Science, Mahidol University," Master of Arts (Educational Informatics), Graduate School, Silpakorn University, 2016.

[19] W. Phetwong, "Development of institutional repositories for research publications of Rajamangala University of Technology," Thesis of Philosophy in Information Studies, Graduate School, Khon Kaen University, 2012.

[20] J. Wang, "Application of blending learning based on network learning space in teching design of digital art," International Journal of Emerging Technologies in Learning (iJET), 2019, vol. 14, no. 3, pp. 177-189.

[21] DSTI, Working Party on Measurement and Analysis of the Digital Economy: Skills for a Digital World, Mexico: OECD publications, 2016.

[22] S. Kolowich, "The professors who make the MOOCs," Chronicle of Higher Education, 2013, vol. 59, no. 28, pp. A20-A23.

[23] P. Nilsook. (October 2018). Designing MOOC content for teaching and learning. [Online]. Available: https://bit.ly/2YdtA7o

[24] Thailand Cyber University, Guidelines for the development of teachers to prepare for open online teaching for the masses, Bangkok: Office of the Higher Education Commission, 2018.

[25] N. Wipawin and R. Withayawuttikul, "Massive open online course (MOOC) and the challenges of the university library," TLA Research Journal: Journal of the Thai Library Association, 2014, vol. 7, no. 1, pp. 78-89.

[26] TPQI. (July 2019). Digital literacy. [Online]. Available: https://bit.ly/29WCmTg

[27] IC3. (July 2019). IC3 Digital literacy certification. [Online]. Available: https://bit.ly/2K3pQjN

[28] ICDL. (July 2019). The international computer driving license. [Online]. Available: http://www.icdlasia.org/

[29] MOS. (July 2019). Microsoft office specialist (MOS). [Online]. Available: https://www.arit.co.th/th/certificate/mos

[30] Office of the Education Council, National Education Plan 2017-2036, Bangkok: Graphic sweet pepper, 2018.

[31] N. Thanachawengsakul, P. Wannapiroon, and P. Nilsook, "The knowledge repository management system architecture of digital knowledge engineering using machine learning to promote software engineering competencies," International Journal of Emerging Technologies in Learning (iJET), 2019, vol. 14, no. 12, pp. 42-56.

[32] A. Voratitipong, P. Wannapiroon, and P. Nilsook, "Digital-education scenario for Thailand". International Journal of Innovatio, Management and Technology, 2019, vol. 10, no. 2, pp. 97-103.

[33] L. Bianca, "Technological innovation, entrepreneurship and internationalization for colombian culture," International Journal of Innovatio, Management and Technology, 2019, vol. 10, no. 1, pp. 43-50.

Copyright $\odot 2020$ by the authors. This is an open access article distributed under the Creative Commons Attribution License which permits unrestricted use, distribution, and reproduction in any medium, provided the original work is properly cited (CC BY 4.0).

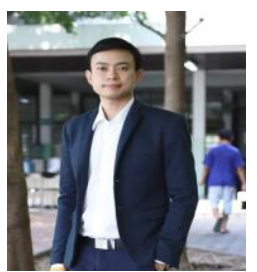

Nattatphol Thanachawengsakul is currently working as an instructor for a bachelor of education program in computer, Faculty of Science, and holds the position of assistant dean, academic division, Faculty of Management Science, Chandrakasem Rajabhat University. Nattatphol Thanachawengsakul, Ph.D. has expertise in system analysis and design, information and communication technology for education, knowledge management in educational institutions, measurement and evaluation in education, educational management with the use of information and communication technology and research of information and communication technology for education. His Doctor of Philosophy in Information and Communication Technology was awarded a by King Mongkut's University of Technology North Bangkok, Thailand. 